\title{
Dakwah di Era Milenial
}

\section{Sukarni}

Institut Agama Islam Negeri Parepare

e-mail: sukarni@iainpare.ac.id

\begin{abstract}
Abstrak
Artikel ini membahas tentang Dakwah dan didalamnya terdapat tentang dinamika dalam berdakwabvh. Seiring dengan perkembangan zaman, kini dakwah dilakukan dengan metode yang sedikit berbeda yaitu dengan berdakwah menggunakan teknologi.Jadi otomatis para pendakwah harus menyesuaikan dengan keadaan agar dakwah terus berkembang
\end{abstract}

Kata kunci: Berdakwah sesuai dengan perkembangan zaman.

\begin{abstract}
The artkel is hot about the wah and inside isabout the dynamic in preaches.

In accordance with the development of time, now the preaching is done A slightly different method is perjuring using technology. So automats the climber had to adapt to the circumstances in order to keep the pace moving
\end{abstract}

Keywords: are preying on the foundation of the apocalypse

\section{PENDAHULUAN}

Berada di abad ke-21 pastinya manusia tidak akan lepas dari bantuan teknologi. Perkembangan teknologi saat ini sangat membawa pengaruh bagi manusia baik itu pengaruh baik maupun pengaruh buruk. Penggunaan teknologi saat ini buka hanya membantu manusia dalam urusan kerja tetapi hampir semua urusan bisa dibantu dengan menggunakan teknologi, tidak terkecuali dalam melakukan dakwah.

Dakwah pada era milenial benar-benar harus memanfaatkan media, utamanya mediamedia baru. Perkembangan teknologi komunikasi telah mengubah cara orang berkomunikasi. Saat ini, hampir setiap orang menggunakan internet dalam mengirim, mencari, dan membaca informasi. Dalam berinteraksi pun kebanyakan melalui media sosial dibanding komunikasi secara langsung. Hal ini sangat dimungkinkan terjadi.setidaknya dipengaruhi beberapa faktor, antara lain pesatnya perkembangan teknologi informasi dan komunikasi, juga kecenderungan masyarakat milenial yang sangat bergantung pada media.

Kaitannya dengan dakwah, peran media sangat strategis dalam upaya penyampaian pesan dakwah. Media mampu menembus batasbatas ruang dan waktu. Artinya, meski dengan jarak jauh komunikasi memungkinkan dilakukan. Tidak hanya itu, media juga 
menawarkan kecepatan waktu dalam menyediakan beragam informasi. Media saat ini tumbuh kian pesat. Dulu, media elektronik seperti televisi dan radio menjadi pilihan favorit dalam mencari informasi. Keunggulannya adalah mampu mengirim pesan suara dan gambar (visual). Saat ini realita itu mulai bergeser. Publik tidak lagi berpusat pada media elektronik sebagai sumber informasi. Justru, kegandrungannya saat ini beralih ke new media (internet).

New Media merupakan perkembangan baru dari media-media yang telah digunakan manusia. Karakternya yang merupakan bentuk digital tentu memudahkan dalam bertukar informasi dan berbagai kegiatan lainnya. New media merupakan media yang dapat meningkatkan interaksi sosial antar manusia contohnya melalui beberapa jejaring sosial namun tetap sesuai kaidah dan norma kesopan-santunan Media baru yang saat ini sedang populer adalah handphone atau smartphone.

Zaman sekarang, bagi sebagian besar masyarakat handphone adalah suatu kebutuhan yang sangat penting bahkan sangat diperlukan. karena semakin berkembangnya teknologi handphone tidak hanya digunakan untuk media komunikasi saja seperti sms atau telpon saja. Sekarang banyak handphone yang menyediakan fitur-fitur untuk browsing, chatting dan lain-lain.

Era milenial menuntut kecepatan dan kemudahan dalam mengakses informasi. Sementara dakwah belum seutuhnya memanfaatkan ragam media yang terus berkembang. Untuk itu, perlu optimalisasi komunikasi dakwah melalui pemanfaatan media baru (new media), utamanya media sosial, mengingat segmentasi mad'u sangat komplek jika ditinjau dari berbagai sisi. Tulisan ini dimaksudkan untuk mengkaji bagaimana mengoptimalkan komunikasi dakwah melalui media sosial dengan cara memanfaatkan fitur-fitur yang ditawarkan. Berdasarkan latar belakang di atas dapat diidentifikasi dua permasalahan utama. Pertama, tantangan dakwah semakin kompleks menghadapi era perkembangan teknologi; Kedua, karakteristik masyarakat milenial yang identik dengan kecenderungannya terhadap media sosial.

\section{PEMBAHASAN}

Dakwah secara etimologis berasal dari kata daa'a yad'u dari bahasa Arab berarti memanggil, mengundang, mengajak, menyeru, mendorong, dan memohon. Secara terminologi, dakwah adalah ajakan, baik berbentuk lisan, tulisan, tingkah laku dan 
sebagainya, yang dilakukan secara sadar dan berencana dalam usaha mempengaruhi orang lain secara individu maupun kelompok agar timbul dalam dirinya satu pengertian, kesadaran sikap penghayatan serta pengalaman terhadap pengajaran agama sebagai message yang disampaikan kepadanya tanpa adanya unsur paksaan. ${ }^{1}$

Kegiatan dakwah ini antara lain didasarkan pada Alquran surah an-Nahl ayat 125:

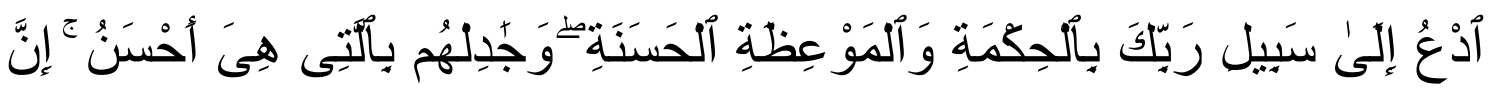

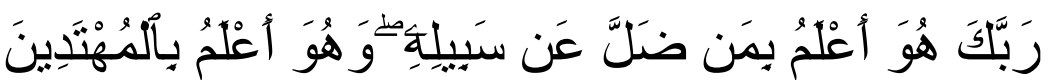

Artinya: "Serulah (manusia) kepada jalan Tuhanmu dengan hikmahdan pelajaran yang baik dan bantahlah mereka dengan carayang baik.Sesungguhnya Tuhanmu Dialah yang lebih mengetahui tentang siapa yang tersesat dari jalan-Nya dan Dialah yang lebih mengetahui orang-orang yang mendapat petunjuk. ${ }^{2}$

Jika ditinjau dari perspektif ilmu komunikasi, maka dakwah termasuk ke dalam komunikasi persuasif karena komunikasi yang dilakukan bertujuan untuk mengubah atau mempengaruhi kepercayaan, sikap, perilaku seseorang sehingga bertindak sesuai apa yang diharapkan oleh komunikator.

\section{Bab}

Dalam proses berdakwah tidak hanya dilakukan kepada satu orang saja atau antar pribadi tetapi bisa juga dilakukan secara kelompok atau lebih dari satu orang. Unsurunsur dakwah terdiri dari pelaku dakwah, penerima dakwah, materi dakwah, media dakwah, metode dakwah dan efek dakwah.

\section{Da'i}

Da'i (pelaku dakwah) adalah orang yang melaksanakan dakwah dengan lisan, tulisan ataupun perbuatan, baik secara individu, kelompok atau berbentuk organisasi atau lembaga.16 Untuk mencapai keberhasilan, pelaku dakwah baik yang secara perorangan maupun kelembagaan, harus mempersiapkan secara matang dalam penguasaan materi, metode, media, dan psikologi.

2. Mad'u

\footnotetext{
${ }^{1}$ Muslimin Ritonga. Komunikasi Islam dan Kehumasan (Yogyakarta: JKPI, 2019) h.63

2 Bobby Rachman Santoso. Revitalisasi Metode Dakwah Anakronistis Dai Generasi Milenial.(Tulungagung : IAIN Tulungagung, 2019) h.140
} 
Mad'u (penerima dakwah) adalah manusia secara keseluruhan, baik yang beragama Islam atau tidak yang menjadi sasaran dakwah atau penerima dakwah,baik secara perorangan atau kelompok. Agar dakwah dapat terarah dan tidak disampaikan secara serampangan, maka diperlukan adanya klasifikasi penerima dakwah seperti berdasarkan usia dan tingkat intelektualitas. Menurut Muhammad Abduh bahwa mad'u terbagi menjadi tiga golongan, yaitu:

a. Golongan cerdik cendikiawan yang cinta kebenaran dan dapat berfikir secara kritis, cepat menangkap persoalan.

b. Golongan awam, yaitu kebanyakan orang yang belum dapat berfikir secara kritis dan mendalam, belum dapat menangkap pengertian-pengertian yang tinggi.

c. Golongan yang berbeda yang dengan golongan di atas adalah mereka yang senang membahas sesuatu, tetapihanya dalam batas tertentu, tidak sanggup mendalami benar.

\section{Materi dakwah}

Materi dakwah adalah isi pesan atau materi yang disampaikan oleh pelaku dakwah kepada penerima dakwah. Dalam penyampaiannya, materi dakwah dapat disampaikan secara menarik agar tidak monoton, aplikatif, agar tidak hanya normatif sehingga dapat merangsang penerima dakwah untuk meningkatkan kualitasnya.

4. Media dakwah

Media dakwah adalah alat yang digunakan untuk menyampaikan materi dakwah kepada penerima dakwah. Ada banyak media yang dapat digunakan sebagai media dalam melaksanakan dakwah. Menurut Hamzah Ya'qub, media dakwah dapat dilakukan dengan lima macam bentuk seperti lisan; tulisan; lukisan atau gambar serta karikatur, dan sejenisnya; audio visual; dan akhlak. Lisan merupakan media dakwah yang paling sederhana. dakwah dengan media lisan dapat berbentuk pidato, bimbingan, dan penyuluhan. Sedangkan media dakwah menggunakan tulisan dapat berbentuk surat menyurat (korespondensi), spanduk, surat kabar, dan buku. Adapun audio visual merupakan alat dakwah yang merangsang indra pendengaran atau penglihatan dan kedua duanya, contoh dari audio visual adalah televisi, film, dan internet. Sedangkan 
akhlak merupakan perbuatan-perbuatan nyata yang mencerminkan ajaran Islam dapat dinikmati serta didengarkan oleh penerima dakwah.

d. Metode dakwah.

Dalam bahasa Inggris, method diartikan metode atau cara. Metode adalah cara untuk menyampaikan sesuatu. Metode juga merupakan cara yang sistematis dan teratur untuk pelaksanaan suatu atau cara kerja. Sedangkan metode dakwah adalah jalan atau cara yang dipakai juru dakwah untuk menyampaikan ajaran materi dakwah (Islam). ${ }^{3}$

Dakwah Zaman Milenial

Peradaban umat manusia pada zaman milenial merupakan era teknologi informasi yang canggih. John Naisbitt, mengungkapkan "we are moving toword the capability to communicate anything to anyone, anywhere, anyfrom-voice, data, textor emage at the speed of light (kita sedang bergerak ke arah kemampuan berkomunikasi apa saja kepada siapa pun, di mana pun, berbentuk apa pun (baik itu) suara, data, tulisan atau gambar (citra) dengan (menggunakan kecepatan suara). Dalam rangka dakwah Islamiyah, kita harus mampu berdialog dengan kebudayaan modern dan secara aktif mengisi dengan substansi dan nuansa

nuansaislami. Hal ini hanya bisa dilakukan bila memahami arus globalisasi secara benar dan tidak tertinggal dengan informasi-informasi aktual dari manca negara. Menurut futurolog John Naisbitt: "The new source oof power is not money in the hands of a few but information in the hands of money" (kekuatan baru dewasa ini bukanlah harta karun di tangan segelintir manusia tapi jaringan informasi di tangan banyak manusia). Ungkapan tersebut merupakan sekelumit gambaran era informasi yang mengglobal dan yang menghadang di hadapan umat Islam dimanapun berada di muka bumi ini. Informasi menurut Islam sangat tidak terbatas. Dalam Al-Qur'an disebutkan:

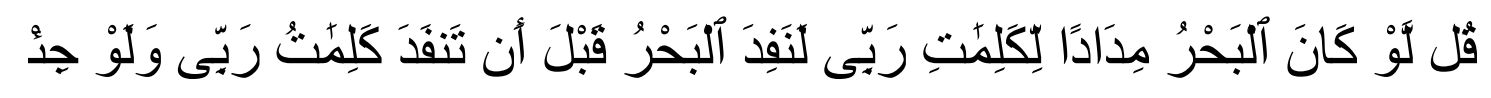

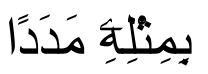

${ }^{3}$ Muslimin Ritonga, Komunikasi Islam dan Kehumasan, h. 67-70 
Artinya: Katakanlah kalau sekiranya lautan menjadi tinta untuk menulis kalimat-kalimat Tuhanku, sungguh habislah lautan itu sebelum habis ditulis kalimat-kalimat Tuhanku, meskipun Kami datangkan tambahan sebanyak itu pula (Q. S. Al-Kahfi: 109). ${ }^{4}$

Karena itu, perlu di kembangkan sistem dakwah yang menggunakan dan memilih teknologi informasi yang efisien dan bersih sesuai dengan kodrat umat manusia. Ini sudah tiba pada suatu masa dimana para da'i mendapat tantangan yang sangat kompleks untuk mencarikan solusi dalam memberikan problem solving.

Pada era milenial, ilmu yang berkembang bersifat multidisipliner dan koplementer. Ilmu agama yang selama ini menjadi pegangan Da'i sebagai sumber utama perlu diperkuat dengan keilmuan lainnya agar apa yang disampaikan kemasyarakat menjadi kokoh dan dapat dioperasionalkan dilapangan. ${ }^{5}$ Para da'i dituntut untuk dapat menerjemahkan pesan Islam sesuai dengan manajemen dakwah modern, efektif dan efisien kepada masyarakat luas, makaIslam akan semakin luas jangkauannya dan mudah dimengerti serta tidak disalahmengertikan oleh non muslim. Dakwah Islam yang damai dan bijak terhadap budaya dan kearifan local ternyata menjadi salah satu kunci keberhasilannya. Jika dulu, sekitar lima ratus tahun yang lalu Sunan Kalijaga mengajarkan Islam di Nusantara dengan cara yang unik melalui kesenian wayang kulit, maka di era milenial metode dakwah beliau harus dilanjutkan. Khususnya adalah spirit cerdas membaca budaya dan perkembangan. Tujuannya satu yakni untuk menciptakan generasi bangsa yang cinta agama dan negara. Sudah pasti cara yang digunakan dalam berdakwah berubah danberkembang seiring dengan perubahan masyarakat. Era kemajuan teknologi bukanlah hambatan, akan tetapi merupakan tantangan. Generasi milenial (muda) harus mampu memaksimalkan kemajuan teknologi untuk sesuatu yang bermanfaat. Bukan sebaliknya, menyalahgunakannya untuk memicu keributan atau menimbulkan keresahan. Di era milenial ini, pemanfaatan teknologi media sosial sangat santer menyentuh berbagai lapisan masyarakat Indonesia, mulai dari masyarakat

Perkotaan hingga masyarakat yang ada di pedesaan yang ada dipelosok nun jauh disana. Usia remaja hingga menginjak dewasa hampir dapat dipastikan pernah mengecap berbagai macam media sosial yang tersedia, mulai dari Facebook, Instagram,

\footnotetext{
${ }^{4}$ Muslimin Ritonga, Komunikasi Islam dan Kehumasan, h. 70-71

${ }^{5}$ Abdul Ghofur. Dakwah dan Komunikasi Islam(Lumajang : IAIS Lumajang, 2019)
} 
Twitter, Youtube ataupun WhatsApp. Beragam media ini sangatlah baik jika digunakan untuk hal-hal yang bermanfaat, seperti contohnya adalah berdakwah. Dakwah adalah kegiatan untuk mengajak atau menyeru kepada Sang Pencipta. Semakin berkembangnya zaman tuntutan dakwah Islam juga menjadi semakin penting. Banyaknya pemikiran maupun gerakan yang berseberangan dengan Islam membuat para generasi muda Islam seperti kehilangan identitas, sehingga diantara mereka tidak sedikit terjebak kepada paham-paham radikal. Berkaitan dengan hal tersebut, para da'i dituntut untuk lebih kreatif dalam mendesain dalam mengkreasikan bentuk dakwah sehingga tidak terkesan ketinggalan zaman. Kegiatan berdakwah zaman milenial amat dibutuhkan eksistensinya dan memiliki berbagai manfaat di antara:

1. Dakwah zaman milenial mencegah pemurtadan.

Belakangan ini sering mendengar kegiatan pemurtadan terhadap umat Islam. Jika kita telusuri, asbabnya bermacam-macam, tetapi yang kerap terjadi kali terjadi adalah faktor ekonomi. Banyakyang memiliki daya ekonomi lemah sangat riskan untuk berpindah keyakinan. Mereka diiming-iming materi dengan tujuan meningkatkan taraf hidup yang lebih baik. Namun demikian, jika ditarik benang merahnya ternyata asbabnya yang paling utama adalah lemahnya iman dan mungkin tidak tersentuh oleh dakwah sehingga dapat berpindah keyakinan.

2. Maraknya budaya Barat yang tidak sesuai dengan ajaran Islam.

Ini menjadi keresahan umat umat Islam, bahwa budaya barat sudah memasuki kalangan generasi Islam. Hampir semua media telah dikuasai Sebagian besar non Islam, sehingga dengan mudahnya mereka memasukkan program yang akan merusak generasi muda Islam khususnya pada aspek akhlak. Generasi milenial disuguhkan dengan dengan film-film, komik, siaran-siaran televisi yang bertengan dengan Islam. Generasi milenial banyak yang terjebak dengan pada prilaku seks bebas, minum-minuman keras dan lain sebagainya.

3. Tongkat estafet menuju era kegemilangan Islam.

Salah satu strategi yang bisa digunakan agar generasi setelahnya, paham dengan ajaran Islam tentu saja melalui dakwah Islam. Dengan dakwah, ilmu-ilmu Islam tidak akan luntur dan akan terus berkembang. Dakwah Islam yang dilakukan pun dapat dilakukan dengan berbagai cara misalnya melalui buku-buku, media , internet, Youtube, WhatsApp, Facebook, dan media sosial lainnya. Berdakwah 
di era milenial berhadapan dengan pesatnya perkembangan teknologi. Dakwah harus menyesuaikan diri dengan perkembangan perangkat yang terus berkembang pesat. Juga, dituntut dapat diakses dengan cepat dengan konten menarik dalam bentuk digital. Terlebih pada era milenial yang kecenderungannya bergantung pada internet, aktivitas sehari-hari cenderung menggunakan media modern. Maka kajian tentang era milenial secara khusus penting dikaji untuk mengetahui pendekatan dakwah seperti apa yang bisa digunakan untuk mencapai kesuksesan dalam berdakwah. ${ }^{6}$

Generasi milenial (sebutan generasi berdasarkan demografi dan disebut juga generasi Y) menjadi perbincangan hangat karena terlahir pada saat revolusi teknologi informasi dan komunikasi serta jumlah populasinya yang cukup besar, yaitu sekira $34 \%$ dari penduduk Indonesia. Umumnya, generasi milenial lahirdalam rentang tahun 1981 sampai 1994. Dengan demikian generasi ini adalah mereka yang berumur 15 hingga 35 tahun.Generasi ini sudah mengenal teknologi seperti komputer, video games, dan smartphone.

Generasi milineal memiliki beberapa karakter sebagai berikut.

1. Generasi Milenial lebih memilih Smarphone sebagai media baca dari pada membaca langsung dari tradisi sebelumnya.

2. Akun media sosialharus dimilki generasi milineal sebagai sarana informasi.

3. Televisi adalah media informasi yang semakin ditinggalkan generasi milineal. Sebeab gedget memiliki keunggulan dari pada melihat siaran televisi.

4. Keluarga adalah sarana pengambilan keputusan bagi generasi milenial. ${ }^{7}$

Beberapa studi tentang generasi milenial menggambarkan mereka yang terkatagori milenial dalam berkomunikasi banyak menggunakan teknologi komunikasi instan seperti email, SMS, instant messaging dan media social sepertiFacebook, Line, Path, Instagram, Whatsapp dan Twitter. Mereka juga suka main gameonline. Generasi

${ }^{6}$ Muslimin Ritonga, Komunikasi Islam dan Kehumasan, h. 72-73

7 Bobby Rachman Santoso, Revitalisasi Metode Dakwah Anakronistis Dai Generasi Milenia,h.139 
ini dikenal sangat senang menghabiskan hidupnya di jejaring media daring. Generasi ini melihat dunia tidak secara langsung melainkan hidup di dunia maya. Mulai dari berkomunikasi, berbelanja online, mendapatkan informasi, dan kegiatan lainnya. Inilah tantangan sekaligus peluang dakwah yang harus dieksekusi. Untuk itu, ada dua hal yang dapat dilakukan. Pertama, terkait dengan penggunaan media dakwah. Pada era digital saat ini, gadget dan media sosial tidak lepas dari generasi milenial. Maka, gadget dan media sosial harus dijadikan wasilah dakwah. Pesan dakwah harus dikemas melalui konten-konten yang akrab dengan generasi kekinian. Penggunaan portal dakwah dengan konten tidak selalu berupa tulisan, namun juga dapat dikemas dalam bentuk vlog, soundcloud, infografis, dan juga meme, dimuat di YouTube agar dakwah makin meluas. Dakwah juga dapat dilakukan secara online dengan memanfaatkan YouTube, Instagram, dan sebagainya, sebelum akhirnya bisa fenomenal secara offline. Kedua, pengemasan pesan-pesan dakwah harus menarik. Sebab, sebaik apapun materi dakwah tanpa didukung dengan kemasan yang menarik terkadang ditinggalkan orang. Dengan dua pendekatan tersebut tantangan dakwah pada generasi milenal dapat dilalui dan diselesaikan dengan baik. Jadi, berbicara dakwah milenial tidak bisa terlepas kaitannya dengan zaman dahulu. Dahulu para Walisongo di Jawa misalnya, dalam menerapkan strategi atau metode dakwah pada masa itu melalui dengan seni seperti meneyebarkan dakwah melalui wayang, teater dan sastra.

Sekarang zaman milenial ini dengan menggunakan strategi melalui new media seperti internet dan media sosial lainnya. Sekarang tinggal bagaimana para juru dakwah atau pelaku dakwah menggunakan media-media komunikasi modern sedemikian rupa untuk hal-hal yang konstruktif dan bermanfaat untuk kepentingan dakwah. Dakwah diera milenial saat ini sangatlah berpengaruh baik terhadap masyarakat tidak terkecuali oleh mahasiswa untuk lebih mengetahui banyak tentang agama. "Dakwah era milenial tidak akan pernah lepas dari teknologi dan masyarakat sekarang pun tidak lepas dari teknologi jadi teknologi sangat membantu para pendakwah untuk menyampaikan ajaran-ajaran agama”. (Salwa Nur mahasiswa IAIN Parepare).

\section{Simpulan}

Kegiatan berdakwah di era milenial ini, dapat dilakukan dengan pemanfaatan teknologi media social yang sangat menyentuh berbagai kalangan masyrakat Indonesia, mulai dari masyarakat perkotaan hingga masyarakat yang ada di pedesaan. Usia remaja hingga social yang tersedia, mulai dari facebook, Instagram, Twitter, Youtube atau 
WhatsApp.beragam media ini sangatlah baik jika digunakan untuk hal-hal yang bermanfaat, seperti contohnya adalah berdakwah.

Salah satu metode yang dianggap masih efektif untuk digunakan sebagai media dakwah adalah dengan memanfaatkan new media seperti internet, facebook, whatsapp dan media sosial. Dengan sarana new media ini akan memudahkan dakwah milenial kecanggihan media informasi dan teknologi menjwab segala kebutuhan manusia masa kini.

\section{DAFTAR PUSTAKA}

Ghofur, Abdul. 2019. Dakwah dan Komunikasi Islam. Volume 5, nomor,2. Agustus.

Muslimin, Ritonga. 2019. Komunikasi Islam dan Kehumasan. Volume 3, nomor 1.

Salwa, Nur (Mahasiswa), Wawancara oleh Sukarni. Institut Agama Islam Negeri Parepare. Tanggal 19 Juli 2020.

Rachman Santos, Bobby. 2019. Revitalisasi Metode Dakwah Anakronistis Dai Generasi Milenial. Volume 17, nomor, 1. Desember. 